
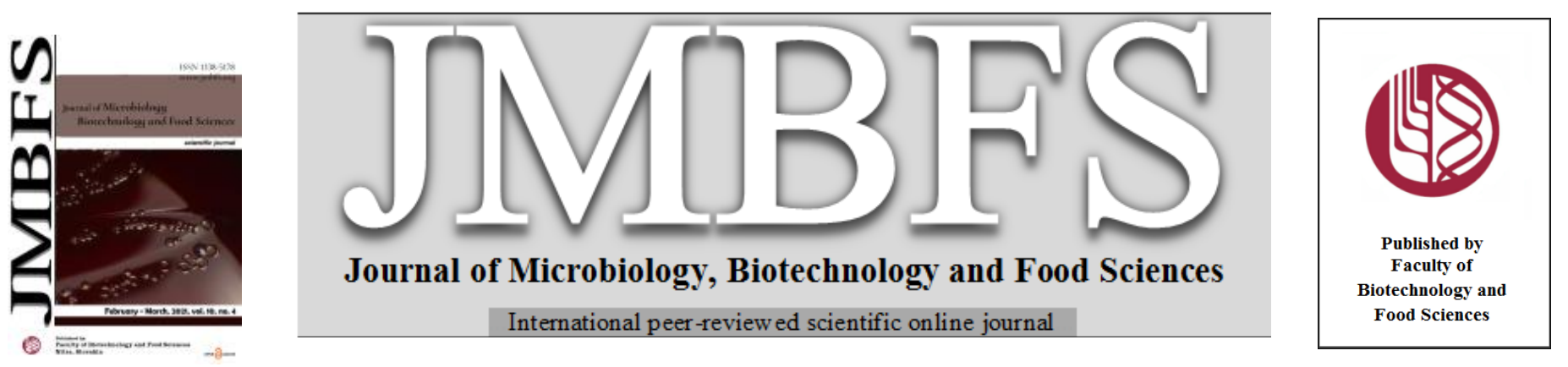

\title{
CONVERSION OF WHEAT STRAW INTO FERMENTABLE SUGARS USING CARBOXYMETHYL CELLULASE FROM TRICHODERMA VIRIDE THROUGH BOX-BEHNKEN DESIGN AND ARTIFICIAL NEURAL NETWORK
}

\author{
Rubina Nelofer ${ }^{1}$, Muhammad Nadeem ${ }^{l}$, Muhammad Irfan ${ }^{2 *}$, Quratulain Syed $^{l}$, Sara Nawaz ${ }^{3}$, Arifa Tahir ${ }^{3}$ \\ Address(es): Dr. Muhammad Irfan, \\ ${ }^{1}$ Pakistan Council of Scientific \& Industrial Research Laboratories, Food \& Biotechnology Research Center, Ferozpure road, 54600 Lahore, Pakistan. \\ ${ }^{2}$ University of Sargodha, Faculty of Science, Department of Biotechnology, University Road, 40100 Sargodha, Pakistan. \\ ${ }^{3}$ Lahore College for Women University, Biotechnology Department, Jail Road 54000 Lahore, Pakistan.
}

*Corresponding author: irfan.biotechnologist@gmail.com

doi: 10.15414/jmbfs.2021.10.4.626-630

\section{ARTICLE INFO}

Received 5. 3. 2019

Revised 6. 10. 2020

Accepted 27. 10. 2020

Published 1. 2. 2021

Regular article

open $\bigodot_{\text {ACCESS }}$

\begin{abstract}
In this study, carboxymethyl cellulase was produced in submerged fermentation characterized and saccharification was optimized through Box-Behnken design. The optima $\mathrm{pH}$ and temperature of enzyme produced by Trichoderma viride were 5 and $50 \mathrm{oC}$, respectively. The crude enzyme had $K m$ and $\operatorname{Vmax}$ values of $1.5143 \mu \mathrm{M}$ and $0.9253 \mu \mathrm{M} / \mathrm{min}$, respectively, using carboxymethyl cellulose as substrate respectively. Three variables including $\mathrm{pH}$ (X1), incubation temperature (X2) and substrate concentration (X3) with three levels were used to optimize saccharification of wheat straw having $83 \%$ cellulose content using Box Behnken design and Artificial Neural Network (ANN). Results reveal that the proposed model was significant and quadratic effect of these parameters significantly affects the sugar production. Maximum sugar production $(28.87 \mathrm{mg} / \mathrm{ml})$ was predicted at RSM predicted levels of $\mathrm{pH}(6.6)$, incubation temperature $\left(50{ }^{\circ} \mathrm{C}\right)$ and $(6.2 \%)$ substrate concentration, while the levels predicted for $\mathrm{pH}$, temperature and substrate concentration were $5,50{ }^{\circ} \mathrm{C}$ and $3.5 \%$, respectively, by ANN. The predicted sugar concentration at these levels was $30.72 \mathrm{mg} / \mathrm{mL}$. The observed values at the predicted levels of RSM and ANN were 25.52 and $29.95 \mathrm{mg} / \mathrm{mL}$ respectively.
\end{abstract}

\section{INTRODUCTION}

Saccharification is a major step in production of bioethanol from lignocellulosic biomass. However, the enzyme cellulase is used as a tool that converts cellulose into fermentable sugars. Cellulase is a complex of three types of enzyme: exoglucanase, endoglucanase and $\beta$-glucosidase that have different modes of action in hydrolysis process (Dawson and Boopathy 2008). The applications of cellulase range from food and paper to the textile industry as well as in production of biofuel from agro wastes. In nature, many microorganisms have inducible synthesis of cellulase that hydrolyzes cellulose to sugars that they used for their growth. Among these microorganisms, Trichoderma viride, Trichoderma reesei and Aspergillus niger are promising strains for cellulase production (Ahamed and Vermette, 2008; Dhillon, et al., 2011; Yasmin, et al., 2013)

The cost of enzyme production is a main obstacle for its commercial production and it causes inexhaustible issues for research. Therefore, it needs to develop the economical production process for cellulases enzymes (Gerdal, 2006). Severa methods have been reported but most feasible method for cellulase production is from lignocellulosic biomass. It can be produced from various biomasses like byproducts of agriculture (wheat straw, rice husk, corn cob and bagasse). Wheat straw is a byproduct of wheat that is produced in a large quantity annually (Asghar et al., 2015). Some part of wheat straw is burnt in fields after harvesting and sometimes saved for use in other applications like animal feed, industry etc. It comprises of cellulose (34-34\%) hemicellulose (20-24\%) and lignin (10-19\%) (Kim and Holtzapple 2006).

Saccharification of biomass is the main step that had major impact on production of biofuels and other beneficial molecules. Therefore optimum methods and efficient enzymes are unavoidable to lower the cost of biomolecules production process from biomass (McIntosh and Vancov, 2011). Optimization of enzymatic saccharification provides the maximum yield in the form of optimal levels of all effecting factors. Modern statistical methods including RSM and ANN have many advantages over conventional one parameter at a time technique and give a picture of the process closer to the actual optimal levels with the calculation of all other effects including the interactions and predictions beyond the levels of factors used in the experimental design (Das et al., 2015).
Therefore, the present study was conducted for the optimization of wheat straw saccharification through indigenously produced cellulase enzyme using RSM and ANN. These methodologies well known for their capacities to optimize bioprocesses (Baladhandayutham et al., 2009; Wei, et al., 2017; Uhoraningoga et al., 2018). It is a combination of mathematical and statistical techniques for designing experiment, models building, evaluating the effects obtained from factors and for finding desired responses from optimized parameters (Pandiyan et al., 2014). This study was designed for production and characterization of crude CMCase and statistical optimization of saccharification process. The wheat straw saccharification optimization using ANN method was not found in literature according to our knowledge.

\section{MATERIAL AND METHODS}

\section{Fungal Culture}

The pure culture of Trichoderma viride was obtained from Microbiology Laboratory, Pakistan Council for Scientific and Industrial Research (PCSIR) Labs. Complex, Lahore, Pakistan and maintained on potato dextrose agar (PDA) slants. The culture was streaked on PDA slants and incubated at $35{ }^{\circ} \mathrm{C}$ for 5 days up till the sporulation. The slants were then wrapped in polythene bags and kept in refrigerator at $4-10{ }^{\circ} \mathrm{C}$ for further use.

\section{Pretreated Substrate}

The pretreated wheat straw (Nawaz et al., 2018) was used for saccharification which was obtained from FBRC, PCSIR Labs Lahore, Pakistan. The powder (2 $\mathrm{mm}$ mesh size) substrate (wheat straw) was sealed in polythene bags for further experiments.

\section{Enzyme Production}

Cellulase production was carried out in submerged fermentation using medium composition of $(\mathrm{g} / \mathrm{L})$; pretreated wheat straw $50,\left(\mathrm{NH}_{4}\right)_{2} \mathrm{SO}_{4} \quad 10, \mathrm{CaCl}_{2} 0.5$, $\mathrm{MgSO}_{4} .7 \mathrm{H}_{2} \mathrm{O} 0.5$ and $\mathrm{KH}_{2} \mathrm{PO}_{4} 4.0$ and $\mathrm{pH}$ was maintained at 5.0 with $1 \mathrm{~N}$ 
$\mathrm{HCl} / \mathrm{NaOH}$ (Nawaz et al., 2018). The medium was autoclaved at $121{ }^{\circ} \mathrm{C}$ for 15 min. After that, the medium was cooled and inoculated with $4 \mathrm{~mL}$ (v/v) of fungus spore suspension and incubated at $30^{\circ} \mathrm{C}$ for 7 days. After the end of fermentation time, the fermented broth was filtered through muslin cloth followed by centrifugation at $8000 \mathrm{xg}$ for $10 \mathrm{~min}$ at $4{ }^{\circ} \mathrm{C}$. The clear supernatant obtained was used as crude cellulase enzyme source.

\section{Enzyme characterization and kinetics}

The crude enzyme obtained after fermentation was characterized. For this purpose different temperature $\left(20-70^{\circ} \mathrm{C}\right)$ and $\mathrm{pH}(3-8)$ were used to get the optimal working levels. Different substrate concentrations ranging from 0-20 $\mu \mathrm{mol} / \mathrm{mL}$ were used to obtain the $\mathrm{V}_{\max }$ and $\mathrm{K}_{\mathrm{m}}$ values.

\section{Optimization of wheat straw sccharification}

The sccharification of wheat straw was conducted using indigenously produced cellulase enzyme. For optimization of saccharification, three parameters $(\mathrm{pH}$, Temperature and wheat straw concentration) were optimized using Box Behnken design (BBD). Two methods of optimization including RSM and ANN were used for that purpose. A total 13 number of experiments were carried out with three parameters at three levels using BBD (Table $1 \& 2$ ). The obtained results were used for the prediction of experimental yield and optimal levels by RSM and ANN methods. Experiments were also conducted on the optimal predicted levels by the two methods. The selected ANN used 3 experiments for the selection of model, 7 experiments to train the network, and 3 experiments to test the model (Table 2). The topology of the network was consisted of three neuron layers, one input layer of three neurons, one hidden layer of 8 neurons, one output layer of 1 neuron (Figure 1). Saccharification in \% was calculated as follows (Irfan et al., 2016);

$\%$ saccharification $=$ Reducing sugar $(\mathrm{mg} / \mathrm{ml}) /$ Pretreated wheat straw used $(\mathrm{mg} / \mathrm{ml}) \times 100$

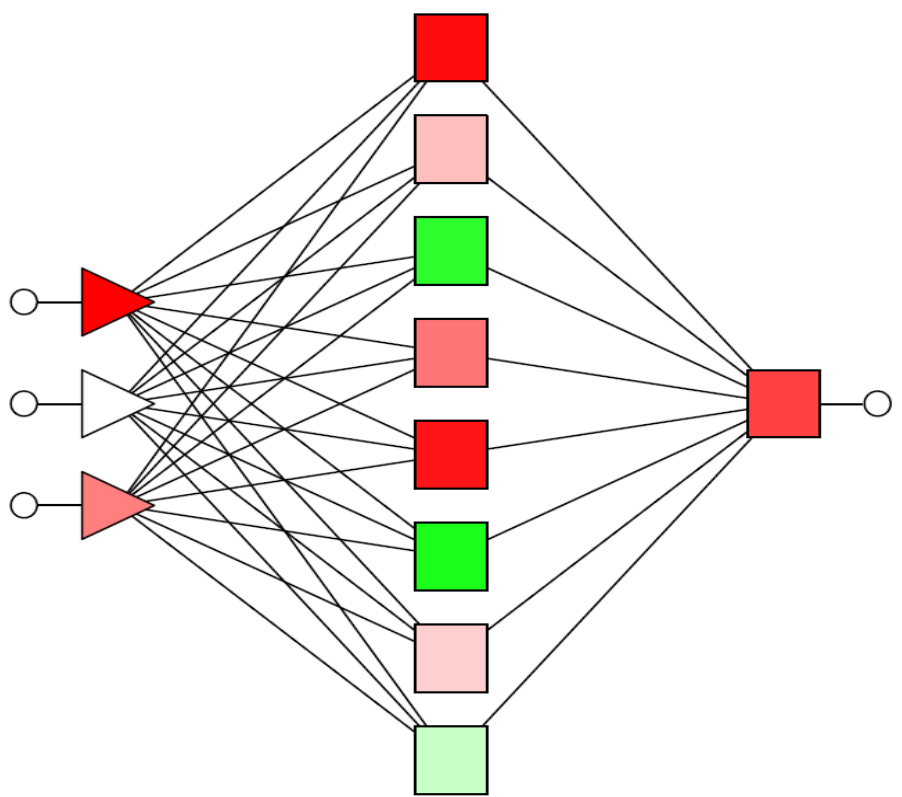

Figure 1 The Topology of the selected ANN showing the three layers structure.

Table 1 Variables and their coded levels used for Box Bhenken Design

\begin{tabular}{l|c|c|c|c}
\hline \multirow{2}{*}{ Variables } & \multirow{2}{*}{ Codes } & \multicolumn{3}{|c}{ Levels } \\
\cline { 3 - 5 } & & -1 & 0 & 1 \\
\hline $\mathrm{pH}$ & $\mathrm{X} 1$ & 3 & 5 & 7 \\
Temperature & $\mathrm{X} 2$ & 30 & 50 & 70 \\
Substrate Conc. (\%) & $\mathrm{X} 3$ & 1 & 3 & 5 \\
\hline
\end{tabular}

\section{Analytical Methods}

Cellulase activity was determined with $1 \%$ (w/v) of carboxymethyl cellulose (CMC) as substrate, in $50 \mathrm{mM} \mathrm{Na-citrate} \mathrm{buffer} \mathrm{having} \mathrm{pH} 4.8$ and incubating at $50^{\circ} \mathrm{C}$ for $30 \mathrm{~min}$. The reducing sugars liberated during the reaction was estimated DNS method of Miller (1959). One unit (IU) of endoglucanase was defined as the amount of enzyme that released $1 \mu \mathrm{mol}$ of glucose equivalent per min under the assay conditions. Reducing sugars were measured by DNS method using glucose as standard.

\section{Statistical analysis}

Experiments were designed and analyzed statistically by STATISTICA software v.7. The variables like $\mathrm{pH}$ (X1), Temperature (X2) and substrate concentrations (X3) having three levels are mentioned in table 1 were used for optimization through Box Bhenken design using RSM and ANN methods.

\section{RESULTS AND DISCUSSION}

In this study endoglucanase (CMCase) enzyme was produced from Trichoderma viride in submerged fermentation using wheat straw as substrate. The crude endoglucanase enzyme was characterized and further utilized for hydrolysis of wheat straw for production of sugars through statistical optimization. The optima $\mathrm{pH}$, temperature and kinetics of crude endoglucanase were determined.

\section{Characterization of the endoglucanase enzyme}

The enzyme activity was tested at various $\mathrm{pH}$ ranges from 3.0-8.0 and results (Fig. 2) showed that endoglucanase enzyme exhibited maximum activity at $\mathrm{pH} 5$. Further change in $\mathrm{pH}$ beyond this resulted decline in enzyme activity. Results of this study was consistent with previous reports. Previously published literature showed that endoglucanase enzyme had optimum $\mathrm{pH}$ of 5 produced from Trichoderma viride (Bhattacharya et al., 2014). Some strains of Trichoderma sp. produced endoglucanase enzyme having optimum $\mathrm{pH}$ of 3.0 (Andrade $\boldsymbol{e}$ t al., 2011). The optimum pH of 4.0 (Yasmin et al., 2013) and 6.0 (Taha et al., 2014) had been reported for endoglucanase from Trichoderma viride.

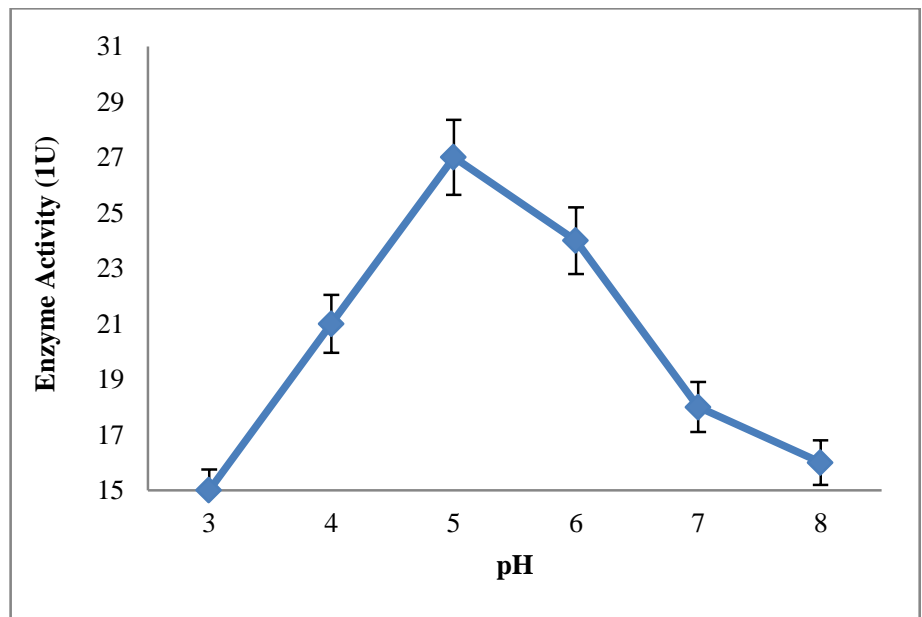

Figure 2 Effect of different $\mathrm{pH}$ on CMCase activity produced from Trichoderma viridi in submerged fermentation.

Endoglucanase activity was checked at different temperature ranging from 25-60 ${ }^{\circ} \mathrm{C}$ to find the optimum temperature of enzyme. Results (Fig. 3) revealed that enzyme activity was increased by increasing temperature from $25{ }^{\circ} \mathrm{C}$ to onward and peak activity was observed at $50{ }^{\circ} \mathrm{C}$. Further increase in temperature led to decline in enzyme activity. Our findings were in line with previous literature that also showed the optimum temperature of $50{ }^{\circ} \mathrm{C}$ from Trichoderma viride (Yasmin et al., 2013; Bhattacharya et al., 2014; Taha et al., 2014). Iqbal et al., (2011) reported $55{ }^{\circ} \mathrm{C}$ optimum temperature of cellulase produced from Trichoderma viride. Andarde et al., (2011) reported that cellulases produced from Trichoderma sp. IS-05 had optimum temperature of $60^{\circ} \mathrm{C}$.

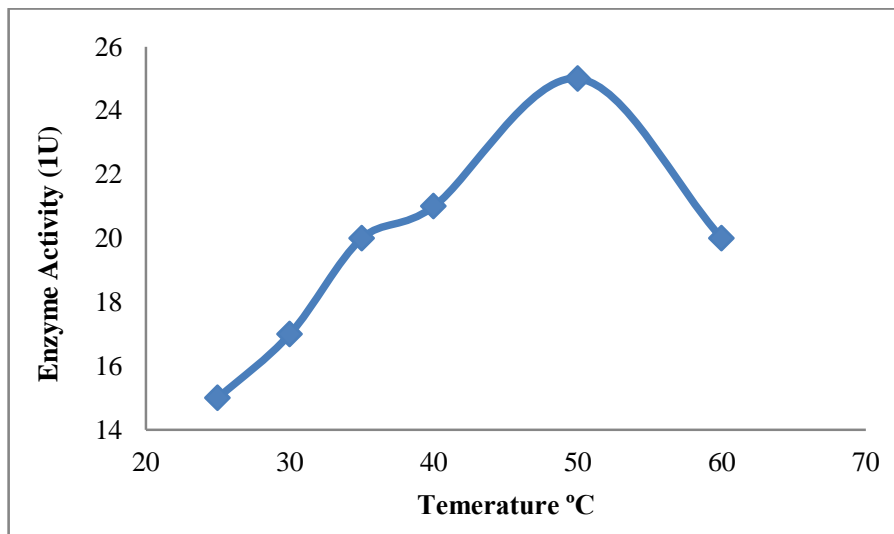

Figure 3 Effect of different incubation temperature on CMCase activity produced from Trichoderma viridi in submerged fermentation. 
Kinetics of the crude endoglucanase was studied by carboxymethyl cellulose as a substrate. Vmax and $\mathrm{Km}$ value was found to be $1.5143 \mu \mathrm{M}$ and $0.9253 \mu \mathrm{M} / \mathrm{min}$ (Fig. 4). Cellulase produced from Trichoderma longibrachiatum exhibited $\mathrm{Km}$ and Vmax of $0.121 \mathrm{mg} / \mathrm{ml}$ and $0.421 \mu \mathrm{mol} / \mathrm{min}$ using carboxymethyl cellulose as substrate (Pachauri et al., 2017). Bhattacharya et al., (2014) reported $\mathrm{Km}$ and Vmax values $0.53 \mathrm{mg} / \mathrm{ml}$ and $83.7 \mathrm{ug} / \mathrm{min}$ for cellulase produced from Trichoderma viride respectively. The cellulase enzyme produced from Trichoderma viride exhibited $\mathrm{Km}$ and Vmax values of $68 \mu \mathrm{M}$ and $148 \mathrm{U} / \mathrm{ml}$ respectively (Iqbal $\boldsymbol{e t}$ al., 2011). Another study conducted on cellulase produced from Trichoderma viride revealed the $\mathrm{Km}$ and Vmax of $2.5 \times 10-5 \mathrm{~g} / \mathrm{l}$ and 75 $\mathrm{g} / \mathrm{lmin}^{-1} \mathrm{mg}^{-1}$ respectively.

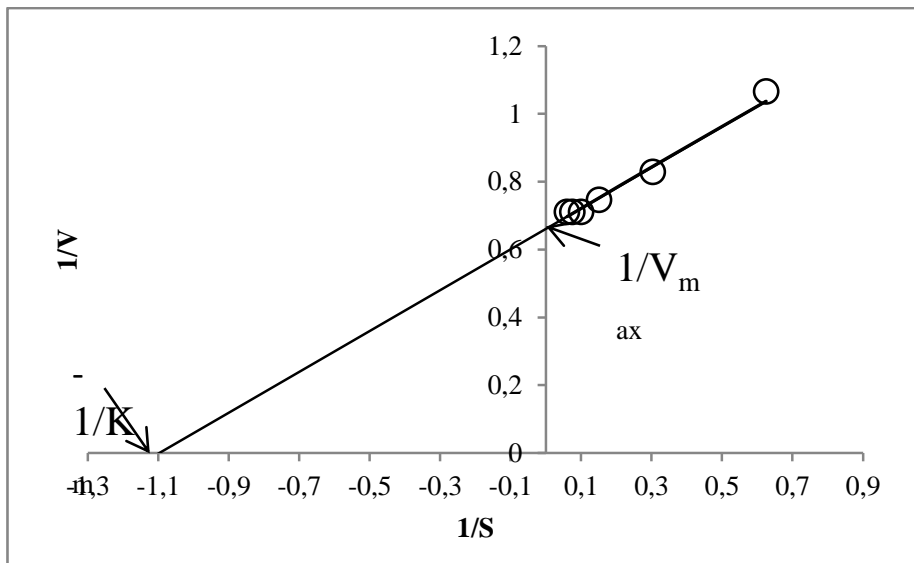

Figure 4 Lineweaver-Burke plot of rate of celluase reaction with different substrate concentrations.

\section{Optimization of pretreated wheat straw saccharification}

Response surface methodology (RSM) is a promising method that is valuable for screening and characterization of various parameters that have significant effects on operating specifications (Thanapimmetha et al., 2012). The close values of observed and predicted response indicated the accuracy of the model (Table 2). Maximum sugar $(24.6 \mathrm{mg} / \mathrm{ml})$ was released at substrate concentration of $1.0 \%$, $\mathrm{pH} 5.0$ and temperature of $50{ }^{\circ} \mathrm{C}$. The response obtained was calculated through polynomial regression as given below.

$\mathrm{Y}($ Sugar $\mathrm{mg} / \mathrm{ml})=-121.244+19.656 \mathrm{X} 1+3.18 \mathrm{X} 2+55.350 \mathrm{X} 3+(-1.791) \mathrm{X} 1^{2}$ $+(-0.029) \mathrm{X}^{2}+(-19.350) \mathrm{X}^{2}+(-0.019) \mathrm{X} 1 \mathrm{X} 2$ $+(-0.100) \mathrm{X} 1 \mathrm{X} 3+(-0.243) \mathrm{X} 2 \mathrm{X} 3$

Where $\mathrm{y}$ is the measured response and $\mathrm{X} 1, \mathrm{X} 2, \mathrm{X} 3$ are coded independent variables.

The analysis of variance (ANOVA) was performed to check the effectiveness of the variables. The model was significant having F-value of 22.013 corresponding P-value of 0.013 (Table 3). The coefficient of determination $\left(\mathrm{R}^{2}\right)$ of the proposed model was 0.992 . The linear and square effects were also found very significant affecting sugar production.

The optimal levels predicted by RSM were $\mathrm{pH}$ 6.6, substrate concentration of 6.6 and temperature of $50{ }^{\circ} \mathrm{C}$ with predicted response $28.87 \mathrm{mg} / \mathrm{L}$. This response was confirmed through repeated experiment which was close to the prediction $(25.52$ $\mathrm{mg}, 37.88 \%$ sccharification). The interaction of variables could be understood by plotting response surface plots. These response surface plots represent the three dimensional view of variable affecting sugar production. The interaction effect of temperature and substrate concentration is significant (Table 3) and it has appositive effect on sugar yield (Fig. 5). The most important objective of Response surface methodology (RSM) is to find out the optimum conditions within the operating specification (Karmakar and Ray 2011).

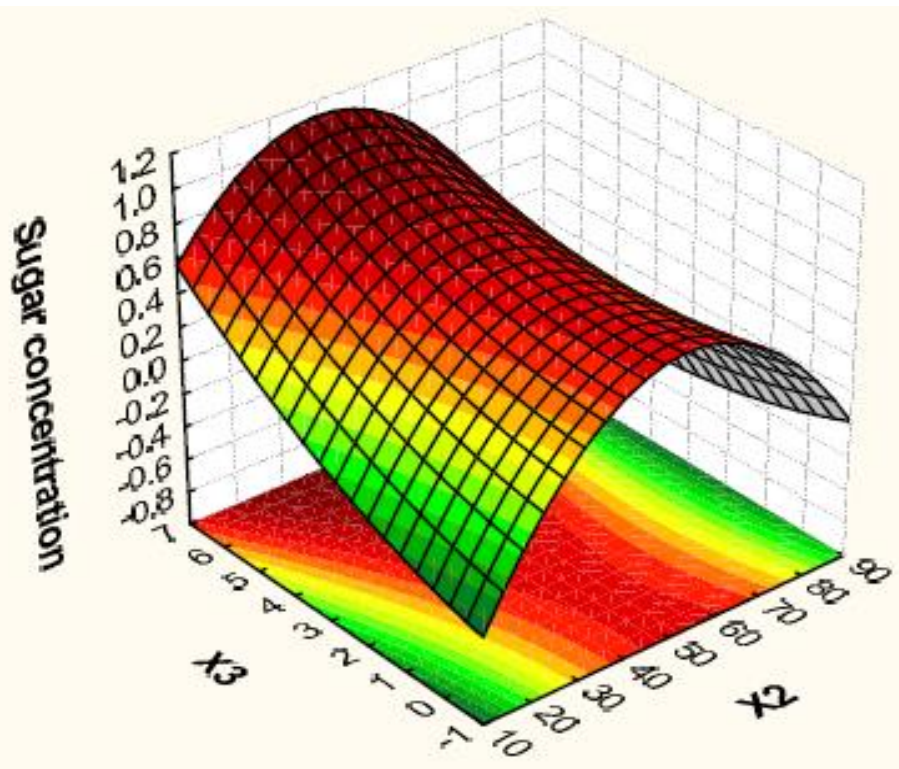

Figure 5 Response surface graph representing the interaction effect of ${ }^{\circ} \mathrm{C}(\mathrm{X} 2)$ and substrate concentration $\%(\mathrm{X} 3)$ on sugar concentration $(\mathrm{mg} / \mathrm{mL})$ calculated by RSM.

RSM method is already being used to optimize alcoholic fermentation (Cristiane et al., 2011). The pervious study was reported that $90.24 \%$ saccharification was achieved from sugar cane tops by Box Bhenken design for the optimization of biomass loading (10\%), enzyme loading (100 FPU/g of cellulase), surfactant concentration $0.04 \%(\mathrm{w} / \mathrm{w}) 72 \mathrm{~h}$ incubation time as reported by Maurya $\boldsymbol{e t}$ al., (2013). Irfan et al., (2016) reported $40.15 \%$ saccharification using $2 \%$ pretreated wheat straw. The earlier study was described RSM parameters where maximum of $3.36 \mathrm{~g} / \mathrm{L}$ ethanol production was achieved under optimum $\mathrm{pH}$ of 5.6 , incubation temperature of $32^{\circ} \mathrm{C}$ and fermentation time $110 \mathrm{~h}$ (Chen et al., 2010; Dhillon 2011).

The Selected ANN on the other hand showed correlation coefficient very close to 1 for the whole model and for the selection, training and test experiments (Table 4), representing the prediction accuracy of the selected ANN. A total number of 50 networks were tested for the selection. The optimum levels predicted by ANN were $5,50{ }^{\circ} \mathrm{C}$ and $3.5 \%$ for $\mathrm{pH}$, temperature and substrate respectively with predicted sugar yield of $30.73 \mathrm{mg} / \mathrm{mL}$. The observed yield on those levels was $29.95 \mathrm{mg} / \mathrm{mL}$ (85.5\% saccharification). The sensitivity test of ANN represents strength of factor's effect on the sugar yield. The maximum effect is of temperature (X2), the next effect is from substrate and the least effect from $\mathrm{pH}$. It was found from the studies that ANN performed better for the wheat straw saccharification optimization in prediction of optimal levels and the sugar yield on those levels. However, the experimental yields of Box-Behnken design are closer to the predicted yields by RSM. The interaction effects are also quantified by RSM as compared to ANN (Nelofer et al., 2012). The interaction effect of temperature and substrate concentration on sugar yield was represented in Figure 6 calculated by ANN.

In most of the cases in optimization of bioprocesses ANN performed better than the RSM (Zafar et al., 2012; Nelofer et al., 2012; Siddique et al., 2014; Titah et al., 2018). In the present studies ANN gave the prediction of optimal levels close to the actual with $85.5 \%$ saccharification of wheat straw. No studies were found on the saccharification optimization of wheat straw using ANN method. However maximum saccharifcation of wheat straw obtained by using RSM or other methods to optimize was lower in most of the cases than that obtained in the present study (Hatakka, 1983; Saha et al., 2006; Li et al., 2009). 


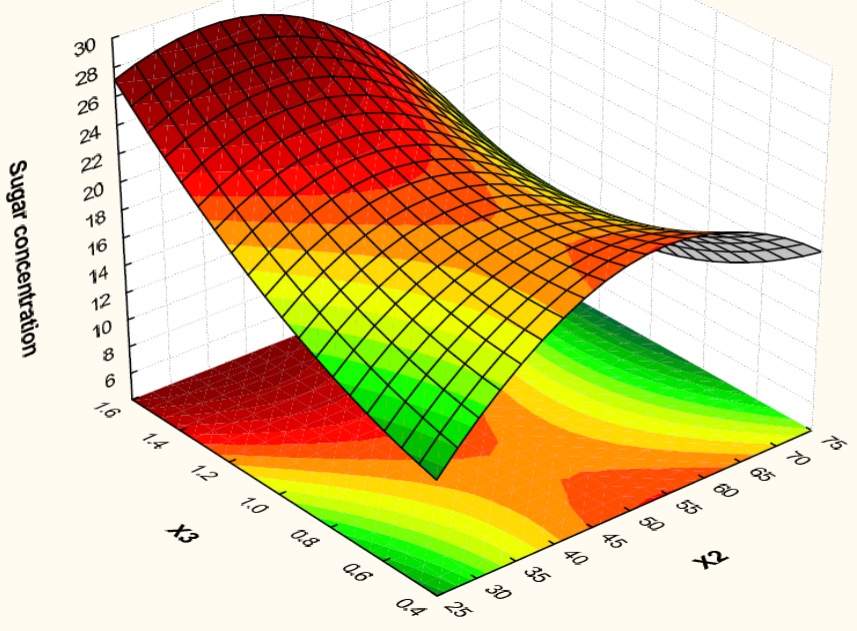

Figure 6 Response surface graph representing the interaction effect of temperature ${ }^{\circ} \mathrm{C}(\mathrm{X} 2)$ and substrate concentration $\%(\mathrm{X} 3)$ on sugar concentration $(\mathrm{mg} / \mathrm{mL})$ calculated by ANN.

Table 2 Box Behnken Design for Optimization of Saccharification by using RSM and ANN

\begin{tabular}{|c|c|c|c|c|c|c|}
\hline \multirow{2}{*}{$\begin{array}{l}\text { Exp. } \\
\text { No }\end{array}$} & \multirow{2}{*}{$\begin{array}{c}\mathrm{pH} \\
\left(\mathrm{X}_{1}\right)\end{array}$} & \multirow{2}{*}{$\begin{array}{l}\text { Temp } \\
\left(\mathrm{X}_{2}\right) \\
\left({ }^{\circ} \mathrm{C}\right)\end{array}$} & \multirow{2}{*}{$\begin{array}{c}\text { Substrate } \\
\text { Conc. } \\
\left(\mathrm{X}_{3}\right)\end{array}$} & \multicolumn{3}{|c|}{ Sugar $(\mathrm{mg} / \mathrm{ml})$} \\
\hline & & & & Observed & $\begin{array}{c}\text { Predicted } \\
\text { by RSM }\end{array}$ & $\begin{array}{l}\text { Predicted } \\
\text { by ANN }\end{array}$ \\
\hline 1 & 7 & 30 & 3 & 21.6 & 20.93750 & 23.25541 \\
\hline 2 & 7 & 70 & 3 & 15.0 & 15.51250 & 14.81959 \\
\hline 3 & 7 & 50 & 1 & 23.3 & 23.11250 & 23.20147 \\
\hline 4 & 7 & 50 & 5 & 26.6 & 26.93750 & 26.69827 \\
\hline 5 & 3 & 30 & 3 & 17.1 & 16.58750 & 17.11524 \\
\hline 6 & 3 & 70 & 3 & 13.5 & 14.16250 & 13.59531 \\
\hline 7 & 3 & 50 & 1 & 20.4 & 20.06250 & 20.29684 \\
\hline 8 & 3 & 50 & 5 & 24.1 & 24.28750 & 23.98887 \\
\hline 9 & 5 & 30 & 1 & 15.8 & 16.65000 & 16.74472 \\
\hline 10 & 5 & 70 & 1 & 17.9 & 17.57500 & 17.93143 \\
\hline 11 & 5 & 30 & 5 & 25.2 & 25.52500 & 26.89628 \\
\hline 12 & 5 & 70 & 5 & 17.6 & 16.75000 & 15.20147 \\
\hline 13 & 5 & 50 & 3 & 24.6 & 24.60000 & 21.67446 \\
\hline
\end{tabular}

*The experiments used for the selection of network are represented by italic, that used for training are represented by bold and the experiments used for testing the $\mathrm{ANN}$ are in normal font.

Table 3 ANOVA for sugar production using RSM

\begin{tabular}{l|c|c|c|c|c}
\hline Source & $\begin{array}{c}\text { Sum of } \\
\text { Square }\end{array}$ & $\begin{array}{c}\text { Degree of } \\
\text { Freedom }\end{array}$ & $\begin{array}{c}\text { Mean } \\
\text { Square }\end{array}$ & F- Value & P- Value \\
\hline Model & 20.64271 & 1 & 20.64271 & 18.44472 & 0.023216 \\
$\mathrm{X}_{1}$ & 10.24111 & 1 & 10.24111 & 9.15066 & 0.056534 \\
$\mathrm{X}_{1}{ }^{2}$ & 6.31750 & 1 & 6.31750 & 5.64483 & 0.097981 \\
$\mathrm{X}_{2}$ & 92.23505 & 1 & 92.23505 & 82.41404 & 0.002824 \\
$\mathrm{X}_{2}{ }^{2}$ & 86.10036 & 1 & 86.10036 & 76.93256 & 0.003121 \\
$\mathrm{X}_{3}$ & 3.14201 & 1 & 3.14201 & 2.80746 & 0.192420 \\
$\mathrm{X}_{3}{ }^{2}$ & 1.00321 & 1 & 1.00321 & 0.89639 & 0.413599 \\
$\mathrm{X}_{1} \mathrm{X}_{2}$ & 2.25000 & 1 & 2.25000 & 2.01042 & 0.251243 \\
$\mathrm{X}_{1} \mathrm{X}_{3}$ & 0.04000 & 1 & 0.04000 & 0.03574 & 0.862119 \\
$\mathrm{X}_{2} \mathrm{X}_{3}$ & 23.52250 & 1 & 23.52250 & 21.01787 & 0.019489 \\
\hline
\end{tabular}

Table 4 Statistical values calculated by ANN for the selection, training, testing and overall experiments.

\begin{tabular}{lcccc}
\hline Parameters & Training & Selection & Test & Overall \\
\hline Data Mean & 19.22857 & 20.23333 & 22.46667 & 20.20769 \\
Data S.D. & 4.41482 & 3.21075 & 3.44996 & 4.16108 \\
Error Mean & -0.02206 & 0.83386 & -1.20926 & -0.09851 \\
Error S.D. & 0.10148 & 0.72032 & 2.06577 & 1.26433 \\
Abs E. Mean & 0.09071 & 0.89955 & 2.34012 & 0.79646 \\
S.D. Ratio & 0.02299 & 0.22435 & 0.59878 & 0.30385 \\
Correlation & 0.99974 & 0.97478 & 0.92459 & 0.95683 \\
\hline
\end{tabular}
0.99974 0.97478
Table 5 Rank and ratio values calculated by ANN for the four parameters used in the experiments.

\begin{tabular}{llll}
\hline Parameters & X1 & X2 & X3 \\
\hline Ratio & 1.346659 & 3.006365 & 2.310417 \\
Rank & 3.000000 & 1.000000 & 2.000000 \\
\hline
\end{tabular}

\section{CONCLUSION}

The results of this study concluded that cellulase enzyme produced from Trichoderma viride actively work at $\mathrm{pH} 5.0$ and temperature of $50^{\circ} \mathrm{C}$. The produced cellulase enzyme effectively hydrolyzed the wheat straw to liberate sugars which could be further used in fermentation process for the production of valuable products such as ethanol. ANN was found to be a better method for the prediction of optimal levels of three factors affecting the sugar yield as compared to RSM.

Acknowledgments: The authors would like to thank the techniacl staff of Food \& Biotechnology Research Center, PCSIR Labs Complex ferozpure road Lahore for experimental facilities.

\section{REFERENCES}

Ahamed, A., Vermette, P. (2008). Culture-based strategies to enhance cellulase enzyme production from Trichoderma reesei RUT-C30 in bioreactor culture conditions. Biochemical Engineering Journal, 40(3): 399-407. https://doi.org/10.1016/j.bej.2007.11.030

Andrade, J.P., Bispo, A.S.R., Marbach, P.A.S., \& Nascimento, R.P., (2011) Production and partial characterization of cellulases from Trichoderma sp. IS-05 isolated from sandy coastal plains of northeast Brazil. Enzyme Research Volume 2011, Article ID 167248, 7 pages https://doi.org/10.4061/2011/167248.

Asghar, U., Irfan, M., Iram, M., Huma, Z., Nelofer, R., Nadeem, M., \& Syed. Q., (2015). Effect of alkaline pretreatment on delignification of wheat straw. Natural Product Research, 29:125-131. http://dx.doi.org/10.1080/14786419.2014.964712 Baladhandayutham, S., Thangavelu, V., \& Ezhumalai, S., (2009). Optimization of process variables using Response Surface Methodology (RSM) in the solidstate fermentative production of pectinase by Aspergillus awamori. Asian Journal of Food Agro-Industries. 2(03), 302-314

Bhattacharya, S., Das, A., Patnaik, A., Bokade, P., \& Rajan, S.S., (2014) Submerged fermentation and characterization of carboxymethyl cellulase from a rhizospheric isolate of Trichoderma viride associated with Azadirachta indica Journal of Scientific and Industrial Research, 73: 225-230.

Chen, W.L., Liang, J.B., Jahromi, M.F., Ho, Y.W., \& Abdullah N. (2013) Optimization of multi- enzyme production by fungi isolated from plam kernel expeller using Response surface methodology. BioResource. 8 : 3844-3857. http://dx.doi.org/10.1537/biores.8.3.3844-3857

Cristiane, S.F., Vitcosque, G.L., Fonseca, R.F., Neto, V.B., \& Couri, S., (2011) Modeling the effects of solid state fermentation operating conditions on endoglucanase production using an instrumented bioreactor. Industrial Crops Products, 34: 1186- 1192. https://doi.org/10.1016/i.indcrop.2011.04.006

Das, S., Bhattacharya, A., Haldar, S., Ganguly, A., Gu, S., A. Ting, A., \& Chatterjee, P. K. (2015). Optimization of enzymatic saccharification of water hyacinth biomass for bio-ethanol: Comparison between artificial neural network and response surface methodology. Sustainable Materials and Technologies. 3: 17-28. https://doi.org/10.1016/j.susmat.2015.01.001

Dawson, L. \& Boopathy, R., (2008). Cellulosic Ethanol Production from sugarcane Bagasse without Enymatic Saccharification. Bioresources 3: 19302126

Dhillon G.S., Brar S.K., Valero, J.R., \& Verma, M., (2011). Bioproduction of hydrolytic enzymes using apple pomace waste by A. niger: applications in biocontrol formulations and hydrolysis of chitin/chitosan. Bioprocess Biosystem Engineering 34:1017-1026. http://dx.doi.org/10.1007/s00449-011-0552-9

Gerdal, B. H., Galbe, M., Grauslund, M. F., Lide'N., G., \& Zacchi, G., (2006). Bio-ethanol - the fuel of tomorrow from the residues of today. Trends in Biotechnology. 24 (12), http://dx.doi.org/10.1016/J.tibtech.2006.10.004

Hatakka, A. I. (1983). Pretreatment of wheat straw by white-rot fungi for enzymatic saccharification of cellulose. European Journal of Applied Microbiology and Biotechnology. 18(6): 350-357.

Iqbal, H.M.N., Ahmed, I., Zia, M.A., \& Irfan, M., (2011). Purification and characterization of the kinetic parameters of cellulase produced from wheat straw by Trichoderma viride under SSF and its detergent compatibility. Advances in $\begin{array}{llll}\text { Bioscience } \quad \text { and } & \text { Biotechnology., } & \text { 149-156. }\end{array}$ http://dx.doi.org/10.4236/abb.2011.23024

Irfan, M., Asghar, U., Nadeem, M., Nelofer, R., Syed, Q., Shakir, H.A., \& Qazi, J.I., (2016). Statistical optimization of saccharification of alkali pretreated wheat straw for bioethanol production. Waste Biomass Valorization. 7: 1389-1396. https://doi.org/10.1007/s12649-016-9540-2

Karmakar, M., \& Ray, R.R. (2011). Statistical optimization of FPase production from water hyacinth using Rhizopus oryzae PR 7. Journal of Biochemical Technology. 3:225-229 
Kim, S., \& Holtzapple, M.T. (2006). Effect of structural features on enzyme digestibility of corn stover. Bioresource Technology. 97:583-591. https://doi.org/10.1016/i.biortech.2005.03.040

Li, Q., He, Y. C., Xian, M., Jun, G., Xu, X., Yang, J. M., \& Li, L. Z. (2009) Improving enzymatic hydrolysis of wheat straw using ionic liquid 1-ethyl-3methyl imidazolium diethyl phosphate pretreatment. Bioresource Technology. 100: 3570-3575. https://doi.org/10.1016/i.biortech.2009.02.040

Maurya, D.P., Vats, S., Rai , S., \& Negi, S. (2013). Optimization of enzymatic saccharification of microwave pretreated sugarcane tops through response surface methodology for biofuel. Indian Journal of Experimental Biology. 51(11):992-6.

Mcintosh. S., Vancov, T. (2011). Optimisation of dilute alkaline pretreatment for enzymatic saccharification of wheat straw. Biomass and Bioenergy. 35(7): 30943103 .

Nawaz, S., Nelofer, R., Tahir, A., \& Syed. Q., (2018) Production of cellulase for ethanol fermentation from pretreated wheat straw. Iranian Journal of Science and Technology Transaction Science. 42: 321-339. https://doi.org/10.1007/s40995016-0050-7

Nelofer, R., Ramanan, R. N., Rahman, R. N. Z. R. A., Basri, M., \& Ariff, A. B. (2012). Comparison of the estimation capabilities of response surface methodology and artificial neural network for the optimization of recombinan lipase production by E. coliBL21. Journal of Industrial Microbiology \& Biotechnology. 39(2): 243-254. http://dx.doi.org/10.1007/s10295-011-1019-3

Pachauri, P., Aranganathan, V., More, S., Sullia, S.B., \& Deshmukh, S., (2017). Purification and characterization of cellulase from a novel isolate of Trichoderma longibrachiatum. Biofuels, https://doi.org/10.1080/17597269.2017.1345357

Pandiyan, K., Tiwari, R., Singh, S., Nain, P.K.S., Rana, S., Arora, A., Singh, S.B., \& Nain, L. (2014) Optimization of Enzymatic Saccharification of Alkali Pretreated Parthenium sp. Using Response Surface Methodology. Enzyme Research

Volume 2014, Article $\quad$ ID 764898, 8 pages http://dx.doi.org/10.1155/2014/764898

Saha, B. C. \& Cotta, M. A. (2006). Ethanol Production from Alkaline Peroxide Pretreated Enzymatically Saccharified Wheat Straw. Biotechnology Progress. 22: 449-453. http://dx.doi.org/doi: 10.1021/bp050310r

Shankar, T. \& Isaiarasu. L., (2012). Statistical optimization for cellulase production by Bacillus pumilus EWBCM1 using response surface methodology. Global Journal of Biotechnology \& Biochemistry. 7 : 01-06.

Siddique, S., Syed, Q., Nelofer, R., Adnan, A., Mansoor, H., \& Qureshi, F. A. (2014). Avermectin B1b Production Optimization from Streptomyces avermitilis 41445 UV 45(m)3 Using Response Surface Methodology and Artificial Neural Network. Journal of the Korean Society for Applied Biological Chemistry. 57(3): 371-378. http://dx.doi.org/10.1007/s13765-013-4172-8.

Taha, A.S.J., Taha, A.J., \& Faisal, Z.G., (2014). Purification and kinetic study on cellulase produced by local Trichoderma viride. International Journal of Advancement in Chemical Engineering \& Biological Science 1(2): 172-175.

Thanapimmetha, A, Vuttibunchon, K., Titapiwatanakun, B., \& Srinophakun, P. (2012). Optimization of Solid State Fermentation for Reducing Sugar Production from Agricultural Residues of Sweet Sorghum by Trichoderma harzianum. Chiang Mai Journal of Science, 39(2): 270-280

Titah, S. H., Halmi, M. I. E. B., Abdullah, S. R. S., Hasan, H. A., Idris, M. \& Anuar, N. (2018). Statistical optimization of the phytoremediation of arsenic by Ludwigia octovalvis- in a pilot reed bed using response surface methodology (RSM) versus an artificial neural network (ANN). International Journal of Phytoremediation. 20(7):

721-729.

http://dx.doi.org/10.1080/15226514.2017.1413337

Uhoraningoga, A., Kinsella, G. K., Henehan, G. T. \& Ryan, B. J. (2018). The Goldilocks Approach: A Review of Employing Design of Experiments in Prokaryotic Recombinant Protein Production. Bioengineering. 5(89). http://dx.doi.org/10.3390/bioengineering5040089.

Wei, P., Si, Z., Lu, Y., Yu, Q., Huang, L. \& Xu, Z. (2017). Medium optimization for pyrroloquinoline quinone (PQQ) production by Methylobacillus sp. zju323 using response surface methodology and artificial neural network-genetic algorithm. Preparative Biochemistry and Biotechnology. 47(7): 709719. https://doi.org/10.1080/10826068.2017.1315596

Yasmin, S., Mattoo, R.L., \& Nehvi, F. A. (2013). Isolation, Characterization and Molecular weight determination of Cellulase from Trichoderma viride. African J. Biotechnol. 12: 4512-4518. http://dx.doi.org/10.5897/AJB2013.12275

Zafar, M., Kumar, S., Kumar, S., \& Dhiman, A. K. (2012). Optimization of polyhydroxybutyrate (PHB) production by Azohydromonas lata MTCC 2311 by using genetic algorithm based on artificial neural network and response surface methodology. Biocatalysis and Agricultural Biotechnology. 1: 70-79. http://dx.doi.org/10.1016/j.bcab.2011.08.012 